\title{
Effect of Different Pot Culture Media on Biochemical and Quality Parameters of Strawberry in Vertical System
}

\author{
K. H. Lakshmikanth*, D. Madaiah and N. Sudharani \\ College of Horticulture, Mudigere, Karnataka, India \\ University of Agricultural and Horticultural Sciences, Shivamogga, Karnataka, India \\ *Corresponding author
}

\section{Keywords}

Strawberry, Media combinations,

Vertical system,

Biochemical and

Quality parameters

Article Info

Accepted:

08 June 2020

Available Online:

10 July 2020

\section{A B S T R A C T}

This study evaluated the biochemical and quality parameters of strawberry cv. 'Winter dawn', in naturally ventilated polyhouse with seven media combinations using six pot culture media viz., soil, sand, farmyard manure, cocopeat, vermicompost and vermiculite under vertical system. The study revealed that maximum TSS $\left(7.73^{\circ}\right.$ Brix $)$, chlorophyll- a $\left(1.82 \mathrm{mg} \mathrm{g}^{-1}\right)$, chlorophyll- $\mathrm{b}\left(0.54 \mathrm{mg} \mathrm{g}^{-1}\right)$, total chlorophyll $\left(2.36 \mathrm{mg} \mathrm{g}^{-1}\right)$, reducing sugar $(5.29 \%)$, non-reducing sugar $(1.16 \%)$, total sugar $(6.45 \%)$, ascorbic acid $(54.80 \mathrm{mg} / 100 \mathrm{~g})$, sugar to acid ratio (6.58) and minimum titratable acidity $(0.98 \%)$ recorded in the media combination having soil + cocopeat + vermicompost in the ratio of 1:1:1 on volume (v/v) basis. Also, the same media combination increased the TSS and ascorbic acid by 28.19 and 7.16 per cent over the control, respectively.

\section{Introduction}

Strawberry (Fragaria $\times$ ananassa Duch.) is an important temperate fruit crop and a regular dietary part of millions of people around the world, due to its delicious taste and pleasant flavor. It is a short-day herbaceous perennial plant belongs to the family Rosaceae, can be grown successfully in the day and cold night temperatures of $22^{\circ} \mathrm{C}$ to $25^{\circ} \mathrm{C}$ and $7^{\circ} \mathrm{C}$ to $13^{\circ} \mathrm{C}$ respectively (De and Bhattacharjee, 2012). The cultivated strawberry is a hybrid between two octoploid species, Fragaria chiloensis Duch. and Fragaria virginiana Duch. (Bowling, 2000) with the diploid chromosome number of $2 \mathrm{n}=56(2 \mathrm{n}=8 \mathrm{x}$, octa ploidy) having a basic chromosome number of $x=7$.

Strawberry is a non-climacteric, fruits mature only on plant and botanically it is an aggregate with soft texture having seeds on the surface of the red fleshy receptacle (Darnell, 2003) called achenes. Strawberry is a nutritious fruit crop and contains a good amount of iron which helps to cure anemia. 
It also contains an anti-cancerous compound called ellagic acid (Wange and Kzlogoz, 1998) that reduces the risk of cancer by $5-50$ per cent, a fair quantity of vitamin $\mathrm{C}$ and vitamin A (60 IU/100 $\mathrm{g}$ of edible portion). Being a rich source of vitamins and minerals coupled with a delicate aroma, Strawberry has become an important table fruit of millions of people around the world (Sharma and Singh, 1990). The pot culture with different media combinations creates the proper growing conditions with sufficient supply of water, macro nutrients, micro nutrients and other required hormones.

The vertical growing system helps in maximum harvest of PAR (photosynthetically active radiations), thereby found to increase the accumulation of photosynthates to increase the quality and biochemical parameters of strawberry. The objective was to know the effect of different pot culture media on biochemical and quality parameters of strawberry in vertical system.

\section{Materials and Methods}

The research was carried out in a naturally ventilated polyhouse of the Department of Fruit Science, College of Horticulture, Mudigere, during 2018-19 in a Completely Randomized Design (CRD) with three replications and seven treatments for the statistical analysis. Mudigere is situated in the Western Ghats, represents the typical climate of hill zone (Zone-9 and Region-V) of Karnataka.

It is located at $13^{\circ} 7^{\prime}$ North latitude and $74^{\circ}$ 37' East Longitude with an altitude of $980 \mathrm{~m}$ above mean sea level (MSL). The experiment tested in three set of vertical system structures each with five tiers constructed using cement blocks with the height and width of $0.8 \mathrm{~m}$ and $2 \mathrm{~m}$, respectively. The pots were filled using six different media viz., soil, sand, farmyard manure, cocopeat, vermicompost and vermiculite. The media combinations were made according to the treatments on volume $(\mathrm{v} / \mathrm{v})$ basis and placed on the vertical system provided with wooden planks. The test variety was "winter dawn". Planting was done in evening, on $2^{\text {nd }}$ November 2018.

Treatment details were $\mathrm{T}_{1}$ - Soil + sand + FYM (1:1:1) (Control), $\mathrm{T}_{2}$ - Soil + cocopeat + vermiculite $(1: 1: 1), \mathrm{T}_{3}$ - Soil + cocopeat + vermicompost $(1: 1: 1), \mathrm{T}_{4}$ - Soil + cocopeat + vermiculite + vermicompost $(1: 1: 1: 1), \mathrm{T}_{5^{-}}$ Cocopeat + vermicompost + FYM $(1: 1: 1), \mathrm{T}_{6^{-}}$ Cocopeat + vermiculite + vermicompost (1:1:1) and $\mathrm{T}_{7^{-}}$Soil + vermiculite + vermicompost (1:1:1). The effects of media combinations on biochemical and quality parameters determined by observing following parameters.

\section{TSS ( ${ }^{\circ}$ Brix)}

It was recorded with the extracted juice using a digital refractometer at room temperature and per cent increase in TSS over the control was estimated.

\section{Chlorophyll content}

Chlorophyll-a, chlorophyll-b and total chlorophyll contents of leaf tissue was determined by using dimethyl sulfoxide (DMSO) method as suggested by Shaof and Lium (1976).

\section{Sugar percentage}

The total sugar content and reducing sugar content of the fruit was estimated by the anthrone method following the method of Ranganna (1977) and expressed in percentage.

Non-reducing sugar $(\%)=$ Total sugar Reducing sugar 


\section{Ascorbic acid (mg/100 g)}

Ascorbic acid was estimated by using 2, 6Dichlorophenol Indophenol titration method (Ranganna, 1986) and expressed in milligram per hundred grams of edible pulp.

\section{Titratable acidity (\%)}

It was calculated in terms of citric acid based on $1 \mathrm{ml}$ of $\mathrm{N} / 10 \mathrm{NaOH}$ equivalent to 0.0067 gram of anhydrous citric or per cent citric acid in juice (Ranganna, 1995).

\section{Sugar to acid ratio}

The sugar to acid ratio was calculated by dividing the total sugars content by the titratable acidity.

\section{Results and Discussion}

The chlorophyll content of leaves varied significantly with different pot culture media combinations except in treatment $\mathrm{T}_{2}$ - Soil + cocopeat + vermiculite (1:1:1), which was on par with the control (Table 1). The highest chlorophyll -a, chlorophyll $-\mathrm{b}$ and total leaf chlorophyll content $(1.82,0.54$ and $2.36 \mathrm{mg} / \mathrm{g}$ of fresh weight respectively) were recorded in treatment $\mathrm{T}_{3}$ - Soil + cocopeat + vermicompost (1:1:1) which was on par with treatment $\mathrm{T}_{6^{-}}$ Cocopeat + vermiculite + vermicompost $(1: 1: 1)$.

The increased chlorophyll content might be due that vermicompost contains available nutrients in the form of nitrate, phosphate, soluble potassium, exchangeable calcium and magnesium, thereby they had a significant positive effect on $\mathrm{N}, \mathrm{P}, \mathrm{K}$ and $\mathrm{Mg}$ content of plants, and $\mathrm{Mg}$ was the central atom of chlorophyll, which intern affected the chlorophyll content in leaves of strawberry with the support of cocopeat and soil, helped in easy uptake of these nutrients (Edwards and Burrows, 1988; Arancon et al., 2004; Sardoei et al., 2014; Abul-Soud et al., 2015). The Significant highest TSS $\left(7.73^{\circ} \mathrm{B}\right)$, ascorbic acid content $(54.80 \mathrm{mg} / 100 \mathrm{~g})$ and significant lowest titratable acidity of 0.98 per cent were recorded in treatment $\mathrm{T}_{3}$ - Soil + cocopeat + vermicompost $(1: 1: 1)$.

Also, the highest per cent increase in TSS $(28.19 \%)$ and ascorbic acid (7.16 \%) over control were observed in the same treatment (Table 2). The lowest TSS and ascorbic acid content $\left(6.03{ }^{\circ} \mathrm{B}\right.$ and $51.14 \mathrm{mg} / 100 \mathrm{~g}$, respectively) were recorded in control, i.e., treatment $\mathrm{T}_{1}$ - Soil + sand + FYM (1:1:1).

The increased TSS and ascorbic acid content of strawberry attributed to the nutritional status of growing media that provide the macro and micronutrients to plant in available forms, and their uptake increased chlorophyll content thereby increased the accumulation of photosynthates (CHOs), which were converted as sugars during the ripening process.

The similar results were also obtained by Grimstand (1990), Koodzeij and Kostecka (1994), Asano (1994) and Abul-Soud et al., (2015). The decrease in titratable acidity might be due to the conversion of higher amounts of organic acids and photosynthates into sugars during the fruit ripening stage (Sharma et al., 2014).

The reduction in titratable acidity may also be due to the utilization of acids as a substrate for respiration during the ripening and neutralization of organic acids by potassium present in tissues (Tisdale and Nelson, 1996).

The significant highest reducing sugar, nonreducing sugar and total sugars content of $5.29,1.16$ and 6.45 per cent were recorded in treatment $\mathrm{T}_{3}$ - Soil + cocopeat + vermicompost $(1: 1: 1)$. 
Table.1 Effect of different pot culture media on chlorophyll content of strawberry in vertical system

\begin{tabular}{|c|c|c|c|}
\hline \multirow{2}{*}{ Treatment } & \multicolumn{3}{|c|}{ Chlorophyll content $\left(\mathbf{m g ~ g}^{\mathbf{- 1}}\right)$} \\
\hline & Chlorophyll- a & Chlorophyll- b & Total chlorophyll \\
\hline $\mathbf{T}_{\mathbf{1}}$ & 1.46 & 0.42 & 1.88 \\
\hline $\mathbf{T}_{\mathbf{2}}$ & 1.52 & 0.44 & 1.96 \\
\hline $\mathbf{T}_{\mathbf{3}}$ & 1.82 & 0.54 & 2.36 \\
\hline $\mathbf{T}_{\mathbf{4}}$ & 1.67 & 0.48 & 2.15 \\
\hline $\mathbf{T}_{\mathbf{5}}$ & 1.73 & 0.51 & 2.24 \\
\hline $\mathbf{T}_{\mathbf{6}}$ & 1.78 & 0.52 & 2.30 \\
\hline $\mathbf{T}_{\mathbf{7}}$ & 1.59 & 0.45 & 2.04 \\
\hline S. $\mathbf{E m} \mathbf{\pm}$ & 0.025 & 0.007 & 0.032 \\
\hline CD @ 5\% & 0.076 & 0.022 & 0.099 \\
\hline
\end{tabular}

Table.2 Effect of different pot culture media on TSS, ascorbic acid, titratable acidity per cent increase in TSS and per cent increase in ascorbic acid of strawberry in vertical system

\begin{tabular}{|c|c|c|c|c|c|}
\hline Treatment & TSS $\left({ }^{\mathbf{o}} \mathbf{B r i x}\right)$ & $\begin{array}{c}\text { Ascorbic acid } \\
(\mathbf{m g} / \mathbf{1 0 0} \mathbf{g})\end{array}$ & $\begin{array}{c}\text { Titratable } \\
\text { acidity }(\mathbf{\%})\end{array}$ & $\begin{array}{c}\text { Per cent } \\
\text { increase in } \\
\text { TSS }\end{array}$ & $\begin{array}{c}\text { Per cent increase } \\
\text { in Ascorbic acid }\end{array}$ \\
\hline $\mathbf{T}_{\mathbf{1}}$ & 6.03 & 51.14 & 1.64 & 0.00 & 0.00 \\
\hline $\mathbf{T}_{\mathbf{2}}$ & 6.37 & 51.87 & 1.41 & 5.63 & 1.43 \\
\hline $\mathbf{T}_{\mathbf{3}}$ & 7.73 & 54.80 & 0.98 & 28.19 & 7.16 \\
\hline $\mathbf{T}_{\mathbf{4}}$ & 6.70 & 53.02 & 1.29 & 11.11 & 3.68 \\
\hline $\mathbf{T}_{\mathbf{5}}$ & 6.90 & 53.93 & 1.15 & 14.43 & 5.46 \\
\hline $\mathbf{T}_{\mathbf{6}}$ & 7.47 & 54.63 & 1.07 & 23.88 & 6.82 \\
\hline $\mathbf{T}_{\mathbf{7}}$ & 6.53 & 52.20 & 1.36 & 8.29 & 2.07 \\
\hline $\mathbf{S . ~} \mathbf{E m} \pm$ & 0.10 & 0.32 & 0.02 & - & - \\
\hline $\mathbf{C D} @ \mathbf{5} \%$ & 0.31 & 0.99 & 0.06 & - & - \\
\hline
\end{tabular}

Table.3 Effect of different pot culture media on reducing sugar, non-reducing sugar, total sugar, sugar to acid ratio and shelf life of strawberry in vertical system

\begin{tabular}{|c|c|c|c|c|}
\hline Treatment & $\begin{array}{c}\text { Reducing } \\
\text { sugar (\%) }\end{array}$ & $\begin{array}{c}\text { Non reducing } \\
\text { sugar }(\mathbf{\%})\end{array}$ & $\begin{array}{c}\text { Total sugar } \\
\mathbf{( \% )}\end{array}$ & Sugar: acid \\
\hline $\mathbf{T}_{\mathbf{1}}$ & 4.24 & 0.88 & 5.12 & 3.12 \\
\hline $\mathbf{T}_{\mathbf{2}}$ & 4.46 & 0.92 & 5.38 & 3.81 \\
\hline $\mathbf{T}_{\mathbf{3}}$ & 5.29 & 1.16 & 6.45 & 6.58 \\
\hline $\mathbf{T}_{\mathbf{4}}$ & 4.95 & 1.01 & 5.96 & 4.62 \\
\hline $\mathbf{T}_{\mathbf{5}}$ & 4.97 & 1.10 & 6.07 & 5.27 \\
\hline $\mathbf{T}_{\mathbf{6}}$ & 5.22 & 1.12 & 6.34 & 5.93 \\
\hline $\mathbf{T}_{\mathbf{7}}$ & 4.83 & 0.98 & 5.81 & 4.27 \\
\hline $\mathbf{S . ~} \mathbf{E} \mathbf{\pm}$ & 0.15 & 0.02 & 0.12 & 0.07 \\
\hline $\mathbf{C D}$ @ 5\% & 0.46 & 0.08 & 0.38 & 0.23 \\
\hline
\end{tabular}



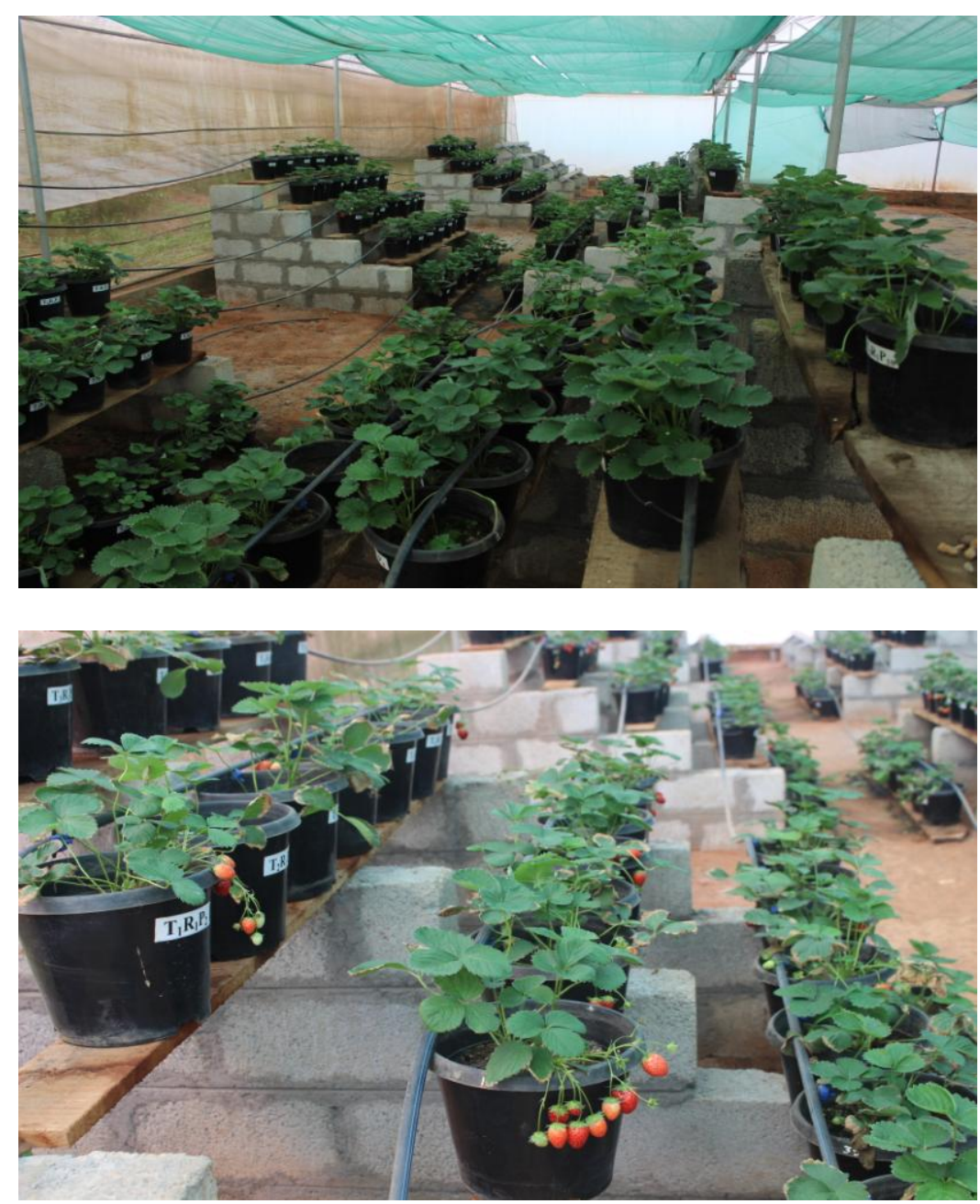

Fig.1 General views of vertical system

The lowest reducing sugar, non-reducing sugar and total sugars content of 4.24, 0.88 and 5.12 per cent was recorded in treatment $\mathrm{T}_{1}$ - Soil + sand + FYM (1:1:1) (control) as presented in table 3 . The highest sugars to acid ratio of 6.58 was recorded in treatment $\mathrm{T}_{3}$ - Soil + cocopeat + vermicompost (1:1:1) and the lowest sugars to acid ratio of 3.12 was recorded in control. The increase in sugars content was due to increased micro nutrients, macro nutrients, carbohydrate $(\%)$ and protein (\%) content as influenced by vermicompost (Khalid et al., 2013; Joshi et al., 2014). Also, the potassium $(\mathrm{K})$ promotes sugar accumulation in berries and balance of $\mathrm{N}, \mathrm{P}$ and $\mathrm{K}$ found essential for proper sugar accumulation of fruits, the increase in total sugars ultimately yielded higher sugars to acid ratio. The similar kind of results were obtained by Ghazvini et al., (2007), Recamales et al., (2007), Ameri et al., (2012) and Lata (2017). The results of the present study revealed that cultivation of strawberry variety "winter dawn" in soil + cocopeat ++ vermicompost media with $1: 1: 1$ combination found better for getting biochemical and quality parameter followed by Cocopeat + vermiculite + vermicompost media with 1:1:1 combination in vertical system under naturally ventilated polyhouse.

\section{References}

Abul-soud, M. A., Emam, M. S. A., Noha, G. and Abd el-rahman, 2015, The potential use of vermicompost in soilless culture 
for producing strawberry. Int. J. Plant \& Soil Sci., 8(5): 1-15.

Ameri, A., Tehranifar, A., Davarynejad, G. H. and Shoor, M., 2012, The Effects of Substrate and Cultivar in Quality of Strawberry. J. Biol. Environ. Sci., 6(17): 181-188.

Arancon. A. N. Q., Edwards, A. C. A., Bierman, B. P., Welch, C. C,. and Metzger, J. D., 2004, Influences of vermicomposts on field strawberries: 1 . Effects on growth and yields. Bioresour. Technol., 93: 145-153.

Asano, J. C., 1994, Effect of organic manures on quality of vegetables. J. Agril. Res., 18(1): 31-36.

Bowling, B. L., 2000, The Berry Grower's Companion. Timber Press Inc., Portland, Oregon, USA. 308p.

Darnell, R., 2003, Strawberry growth and development. The Strawberry: A Book for Growers and Others, held at Florida, Gainesville, (Childers NF ed). Institute of Food and Agricultural Sciences, University of Florida, Gainesville, USA.

De, L. C., and Bhattacharjee, S. K., 2012, Handbook of Edible Fruits. Aavishkar Publishers, Jaipur 302003 (Rajasthan), India. $312 \mathrm{p}$.

Edwards, C. A. and Burrows, I., 1988. The potential of earthworm composts as plant growth media. In: Edwards, C.A. and E. Neuhauser (Eds.). Earthworms in waste and environmental management. SPB Academic Press. The Hague, the Netherlands, pp: 21-32.

Ghazvini, R. F., Payvast, G. and Azarian, H., 2007, Effect of Clinoptilolitic-zeolite and Perlite Mixtures on the Yield and Quality of Strawberry in Soil-less Culture. Int. J. Agri. \& Bio., 9(6): 1-5.

Grimstand, S. O., 1990, Evaluation trials of greenhouse cucumbers. Verdiproving av veksthusagurk. Gartneryrket, 80 (21): 16-18.
Khalid, S., Qureshi, K. M., Hafiz, I. A., Khan, K. S. and Qureshi, U. S., 2013, Effect of organic amendments on vegetative growth, fruit and yield quality of strawberry. Pakistan J. Agri. Res., 26(2): 104-111.

Koodzeij, M. and Kostecka, J., 1994, Some quality characteristics. In cucumber and carrot grown on vermicomposts. ZezytyNaukeme-Akademii- Roluicoz-ej-imHugona-Koataja-w-karkowie, SerjaNaakowa, 41: 89- 93.

Lata, K., 2017, Effect of growing media and fertigation schedules on growth and yield of cucumber (Cucumis sativus L.) under polyhouse condition. M.Sc. thesis, Sri Karan Narendra Agriculture University, Jobner (India).

Ranganna, S., 1977, Manual of analysis of fruits and vegetable products. Tata Mcgrow Hill Pub. Co. Ltd., New Delhi. pp. 255.

Ranganna, S., 1986, Handbook of Analysis and Quality Control for Fruit and Vegetable Products, Tata Mc Graw Hill, New Delhi, pp. 190-210.

Ranganna, S., 1995, Handbook of analysis and quality control for fruits and vegetable products. McGraw-Hill Publishing Company Limited, New Delhi. pp. 1-21.

Recamales, A. F., Medina, J. L. and Hernanz, D., 2007, Physicochemical characteristics and mineral content of strawberries grown in soil and soilless system. J. Food Quality, 30: 837-853.

Sardoei, A. S., Roien, A., Sadeghi, T., Shahadadi, F. and Mokhtari, T. S., 2014, Effect of vermicompost on the growth and flowering of African marigold(Tagetes erecta). AmericanEurasian J. Agric. and Environ. Sci., 14(7): 631-635.

Sharma, G., Yadav, A. and Gara, S., 2014, Evaluation of different strawberry cultivars for yield and quality characters 
in Himachal Pradesh. Agric. Sustain. Dev., 2(1): 59-61.

Sharma, V. P. and Singh, R., 1990, Growth and fruiting behaviour of Strawberry (Fragaria sp.) as affected by clocking and gibberellic acid treatments. Proceedings of $11^{\text {th }}$ International Congress on the use of plastic in agriculture, IARI, New Delhi, pp. 36-41.

Shoaf, J. W. and Lium, B. W., 1976, Improved extraction of chlorophyll a and $\mathrm{b}$ from algae using dimethyl sulfoxide limnol. Oceanogr, 21: 926927.

Tisdale, S. L. and Nelson, W. L., 1996, Soil fertility and fertilizers, Mc. Millan C London.

Wange, R. S. AND Kzlogoz, G. A., 1998, Effect of biofertilizer on growth, yield and quality of Strawberry. Ann. Agric. Sci. Mosthohor, 43(2): 247-254.

\section{How to cite this article:}

Lakshmikanth. K. H., D. Madaiah and Sudharani. N. 2020. Effect of Different Pot Culture Media on Biochemical and Quality Parameters of Strawberry in Vertical System. Int.J.Curr.Microbiol.App.Sci. 9(07): 678-684. doi: https://doi.org/10.20546/ijcmas.2020.907.078 